\author{
Kostiantyn Mamonov, Vyacheslav Frolov ${ }^{1}$, Ivan Kondratyuk ${ }^{2}$, Olena Kanivets ${ }^{3}$ \\ ${ }^{1}$ O. M. Beketov National University of Urban Economy in Kharkiv, Ukraine \\ ${ }^{2}$ LLC "Geodetic Research Center", Ukraine \\ ${ }^{3}$ Sumy National Agrarian University, Ukraine
}

\title{
TERRITORIAL DEVELOPMENT OF LAND USE IN REGIONS: CONCEPTUAL PROVISIONS, PROBLEMS AND A METHODOLOGICAL APPROACH TO ASSESSMENT
}

The relevance and timeliness of ensuring the territorial development of land use at the regional level is determined. The aim of the study is to develop conceptual provisions and a methodological approach to determining and assessing the territorial development of land use in regions. To achieve this goal, the following tasks are solved: identification of problems in the system for ensuring the territorial development of land use in the regions; the formation of conceptual provisions for determining the territorial development of regional lands; development of a methodological approach to assessing the level of territorial development of land use. The problematic aspects are identified and a definition of the concept of «territorial development of land use in the region» is proposed. The directions of the development and implementation of a methodological approach to assessing the territorial development of land use in the regions are described. As a result of the study, an integral indicator of the territorial development of land use in the region was determined, the value of which indicates the need to change its trends by taking measures and developing scientifically sound recommendations for ensuring the territorial development of land use for the transition from a moderate scenario to a growth scenario.

Keywords: land use, territorial development of regions, conceptual provisions, methodological approach, assessment.

\section{Introduction}

In the context of deep transformations taking place at the regional level, solving the issue of ensuring the territorial development of land use is of particular importance. Modern reform of decentralization, a slowdown in the growth dynamics of key regional indicators, significant imbalances and imbalances between regional institutions require a rethinking of approaches to ensuring territorial development. The growth of powers of the united territorial communities, the transfer to them of hundreds of forms and disposition of land contributes to the development of local government. However, problems arise regarding the adoption of sound management decisions regarding land use. Therefore, the topic of the study to ensure the territorial development of the use of land in the regions is relevant and timely.

\section{Analysis of existing research}

Scientists engaged in resolving issues on the formation of directions and ensuring the use of land: [112]. Along with this, the issues of ensuring the territorial development of the use of land in the regions, the formation of conceptual provisions and a quantitative basis for making informed management decisions remain unresolved.

\section{The objectives of the study}

The aim of the study is to develop conceptual provisions and a methodological approach to determining and assessing the territorial development of land use in regions.

To achieve this goal, the following tasks are solved:

- identification of problems in the system for ensuring the territorial development of land use in regions;

- the formation of conceptual provisions for determining the territorial development of regional lands;

- development of a methodological approach to assessing the level of territorial development of land use.

\section{Main part}

In scientific developments, theoretical and methodological provisions are systematized to determine the directions and characteristics of land use, and to ensure territorial development. However, further investigation is required of the problem, which consists in resolving the contradictions between low-structured and fuzzy processes of organization and use of land resources of the regions of Ukraine, leading to conflict situations in land relations and modern methods, techniques and 
technologies that ensure the territorial development of land use in the region. In the context of the problem posed, the following questions were identified: 1) the formation of a theoretical and methodological platform regarding the definition of the territorial development of land use in the region; 2) development of a diagnostic system of indicators for assessing the territorial development of land use in the region; 3) assessment of the territorial development of land use in the region; 4) development of a technology for the formation of an information system for territorial development, taking into account the influence of spatial, urban, investment and environmental factors.

The solution to the problem, the structural component of which is the formation of a theoretical and methodological platform for determining the territorial development of land use in regions, is based on the systematization and formation of conceptual provisions for determining the territorial development of land use in regions, the results of an analysis of its condition and paradigm changes.

As a result of the formation of conceptual provisions, a disconnectedness of theoretical approaches to determining the territorial development of land use in regions has been established, where the main focus is only on certain aspects, in particular spatial, urban, investment or environmental, or a combination of some of them. The presented approaches do not allow to systematically solve the problem of creating a theoretical and methodological basis for determining and evaluating the territorial development of land use, and developing an appropriate mechanism for its provision.

As a result of the analysis of the existing theoretical and methodological provisions, a definition of the territorial development of land use in the regions is proposed, characterized as a combination of spatial, urban, investment and environmental factors, the interaction of which leads to the achievement of a qualitatively new state of land relations compared to the past taking into account social, institutional, and administrative features and the level of interaction of stakeholders operating in the field of land use in the regions.

Territorial development is considered as a systemic permanent process of formation and use of land resources of the regions, is determined by three scenarios: 1) negative - the influence of negative factors exceeds the influence of positive factors. In this case, the negative impact of factors on the use of land resources is minimized; 2) a moderate scenario is determined by balancing the negative and positive influence of factors of territorial development. To ensure the territorial development of the use of land in the regions, a basis is formed for the transition to a growth scenario; 3) the growth scenario is characterized by an excess of the positive influence of factors over the negative. In this context, territorial development is ensured on the basis of increasing the level of land use efficiency in the regions.

The degree of influence of factors is determined on the basis of established types of relationships (inverse or direct) between spatial, urban, investment and environmental factors, the systemic factor of the territorial development of land use in the regions. Certain bonds and their density (stability) are affected by the values of the correlation coefficients. If the value of the correlation coefficient varies in the range from 0 to 0.49 , then the relationships are unstable. In other cases $(0.5-1)$ - stable.

The author's definition of the territorial development of land use in the regions is proposed, characterized as a combination of spatial, urban, investment and environmental factors, the interaction of which leads to the achievement of a qualitatively new state of land relations in comparison with the past, taking into account social, institutional, managerial features and the level of interaction of stakeholders operating in the use of land in the regions.

Based on the developed conceptual provisions, a theoretical and methodological platform has been formed to determine the territorial development of land use in the regions to increase the efficiency of their use in a dynamic market environment, based on a systematic approach, information and analytical support, methodological analytical procedure, with the possibility of determining a scenario for further development. This made it possible to single out conceptual provisions for determining the territorial development of land use in regions, to establish the influence of spatial, urban, investment and environmental factors, to develop a methodology for the integrated assessment of the systemic factor of territorial development. The theoretical and methodological platform provides opportunities for the implementation of geofactorial analysis, as a modern tool for establishing the influence of factors on the territorial development of land use in regions.

To assess the territorial development of the use of land in the regions, a methodological approach is appropriated. The essence of this approach is to apply the results of geofactorial analysis, a combination of integrated, analytical, expert methods and methods for analyzing hierarchies, neural networks, determining the geometric mean, quasimetric models, allows you to assess the level of territorial development of land use in the region, taking into account spatial, urban, investment and environmental factors.

The implementation of the methodological approach to the integrated assessment of the territorial development of land use in the regions is based on the principles of:

- scientific validity: characterized by determining the level of territorial development, based on scien- 
tific and methodological developments, regulatory support;

- complexity: includes a set of indicators that combine spatial, urban, investment and environmental factors and is determined by interrelated actions aimed at determining the level of territorial development of land use in regions;

- consistency: it is determined by a multi-level system of spatial, urban, investment and environmental indicators that create an estimated basis for the territorial development of land use in the regions;

- integrity: characterized by the creation of a unified system for assessing the level of territorial development of the use of land in the regions, it allows to obtain an integral indicator for making informed decisions;

- target orientation: determines the focus on achieving goals aimed at ensuring the territorial development of land use in the regions, given the complex of spatial, urban, investment and environmental factors;

- structuring: characterized by a clear structure of indicators that are defined at various levels;

- development: determined by the development of measures to ensure the territorial development of land use in the regions on the basis of its established levels;

- adequacy: characterized by determining the appropriate levels of territorial development, reflecting the directions and characteristics of the impact and changes occurring in the spatial, urban planning, investment and environmental support.

The development and implementation of a methodological approach to the integrated assessment of the territorial development of land use in the regions includes a set of interrelated stages:

1. Conducting geofactorial analysis for: the formation of a set of spatial, urban, investment and environmental factors affecting the territorial development of land use in the region based on existing scientific and methodological developments and regulatory support; building a multi-level system of factors; selection of factors that have the greatest impact on the territorial development of land use in the region by applying the method of expert assessments.

2. Formation of a multi-level system of indicators by applying quasimetric models of the transition from the proposed factors to the corresponding spatial, urban, investment and environmental indicators, taking into account the values of the assessment coefficients.

3. Assessment of the system of spatial, urban, investment and environmental indicators of the third level based on the application of the analytical and expert assessment methods.

4. Determination of spatial, urban, investment and environmental indicators of the second level by constructing mathematical models based on the method of estimating geometric mean values.
5. The construction of a mathematical model for determining the integral spatial, urban, investment, environmental indicators of the territorial development of land use in the regions.

6. Determination of weight coefficients characterizing the importance of spatial, urban, investment and environmental indicators in the system of territorial development of land use of regions based on the application of the method of analysis of hierarchies.

7. Determination of the integral spatial, urban, investment, environmental indicators of the territorial development of land use in the regions.

8. Assessment of the integrated indicator of land use in regions.

9. Development and justification of a scale of levels of territorial development of land use in regions.

10. Interpretation of the obtained results.

Based on the application of the methodological approach, the integral indicator of the territorial development of the use of land of the regions is determined (Table 1).

Table 1

Assessment results of the integrated indicator of territorial development of land use in the regions, rel. units

\begin{tabular}{|c|c|}
\hline Region & Indicator value \\
\hline Vinniczkij & 1,824 \\
\hline Voly`nskij & 1,819 \\
\hline Dnepropetrovskij & 1,820 \\
\hline Doneczkij & 1,819 \\
\hline Zhitomirskij & 1,821 \\
\hline Zakarpatskij & 1,821 \\
\hline Zaporozhskij & 1,817 \\
\hline Ivano-Frankovskij & 1,824 \\
\hline Kievskij & 1,815 \\
\hline Kropivniczkij & 1,821 \\
\hline Luganskij & 1,820 \\
\hline L`vovskij & 1,822 \\
\hline Nikolaevskij & 1,819 \\
\hline Odesskij & 1,800 \\
\hline Poltavskij & 1,831 \\
\hline Rovenskij & 1,820 \\
\hline Sumskoj & 1,806 \\
\hline Ternopol`skij & 1,827 \\
\hline Khar`kovskij & 1,824 \\
\hline Khersonskij & 1,825 \\
\hline Khmel`niczkij & 1,819 \\
\hline Cherkasskij & 1,818 \\
\hline Chernoveczkij & 1,820 \\
\hline Chernigovskij & 1,825 \\
\hline
\end{tabular}


Based on the study, a significant level of territorial development of land use in the regions was determined. Such trends are due to the directions of formation and the trajectory of changes in spatial, investment and environmental indicators. Only urban factors were characterized by high values. The highest values of the integral indicator of the territorial development of land use were observed in the regions: Vinniczkij, Ivano-Frankovskij, Poltavskij, Ternopol`skij, Khar`kovskij, Khersonskij, Chernigovskij. Low values of the integral factor of the territorial development of land use were determined by the regions: Dnepropetrovskij, Doneczkij, Zaporozhskij, Kievskij, Nikolaevskij, Odesskij, Sumskoj, Khmel`niczkij, Cherkasskij, Chernoveczkij.

\section{Conclusions}

As a result of a generalization of the existing theoretical and methodological approaches, a definition of the concept of «territorial development of land use in the region» is proposed, which includes the multidimensionality and features of territorial development, the direction of changes in spatial, urban, investment and environmental factors, allows us to create a theoretical and methodological platform based on the application of a systematic approach conceptual scheme and highlight the dominant direction to solve the problem of increasing the effectiveness of land use for the territorial development of regions, to identify problematic aspects that occur in the sphere of land relations, to combine the positive directions of existing approaches and to develop comprehensive tools for implementing modern methods and models.

Thus, as a result of the study, the terminological apparatus of the scientific specialty cadastre and land monitoring was improved, in particular, it was introduced into the functional field for determining the territorial development of land use in the regions and the implementation of a scenario approach to its support was proposed, taking into account the influence of spatial, urban, investment and environmental factors.

As a result of the study, an integral indicator of the territorial development of land use in the region was determined, the value of which indicates the need to change its trends by taking measures and developing scientifically sound recommendations for ensuring the territorial development of land use for the transition from a moderate scenario to a growth scenario.

\section{References}

1. Avramenko, T.P (2015) Transformation of land resources in the agrarian sector. Scientific Bulletin of Kherson State University, 107- 111.

2. Bogira, M.A., Stupen, M.O. (2012) Problems in land use, caused by the land reform in Ukraine, and ways to overcome them, 16-18.

3. Vysochanskaya, N.Ya. (2015) Foreign experience of using land resources.
4. Dorosh, J.O. Dorosh, O.P. Ecological and economic imperatives of reforming land relations in market conditions, 30-33. 5. Kovtun, O.M. (2011) Legal regulation of programming, use and protection of land in Ukraine: 20-year experience of reforming and prospects of development of land legal relations. Visn. Of the Bar of Ukraine, 231-234.

6. Kosolap, M.P, Krotinov O.P (2011) The system of landslavery, 352.

7. Mosiuk, I.P., Mosiuk, S.I. (2011) Land resource potential of agricultural production and rational nature management of Ukraine. Nauk. Visn. NULES of Ukraine, 259-261.

8. Thomson, P. (1997) Who owns the land in the UK? Proposal, 8 .

9. Shipulin, V.D. (2016) Land administration system: basics of modern theory, 352.

10. Yurchenko, A. (2009) State of Land Policy in Ukraine, 7585.

11. Jantien E. Stoter. (2003) 3D aspects of property transactions: comparison of registration of $3 \mathrm{D}$ properties in the Netherlands and Denmark.

12. Mamonov, K., Nesterenko, S., Radzinskaya, Y., Palama,r A. (2019) The method for assessing the urban land investment attractiveness. Geodesy and Cartography, 321-327.

\section{Література}

1. Авраменко, Т.П. Трансформація земельних ресурсів 6 аграрному секторі. [Текст] / Т.П. Авраменко // Науковий вісник Херсонського державного університету. Серія Економічні науки. № 14. Ч. 1. 2015. С. 107-111.

2. Богіра, М. О. Проблеми у землекористуванні, зумовлені проведенням земельної реформи в Україні, та иляхи їх подолання [Текст] / М. О. Богіра, М.О. Ступень // Землевпоряд. вісн. - 2012. - № 3. - С. 16-18.

3. Височанська, М. Я. Зарубіжний досвід використання земельних ресурсів [Електронний ресурс] / М. Я. Височанська. Агросвіт № 15, 2015. Режим доступу: http://www.agrosvit.info/pdf/15_2015/13.pdf.

4. Дорош, Й. О. Еколого-економічні імперативи реформування земельних відносин в умовах ринку [Текст] / Й.О. Дорош, О. П. Дорош // Там само. - С. 30-33.

5. Ковтун, О. М. Правове регулювання програмування, використання та охорони земель в Украӥні: 20-річний досвід реформування та перспективи розвитку земельних правовідносин [Текст] / О. М. Ковтун // Вісн. Академії адвокатури Украӥни. - 2011. - № 2. - С. 231-234.

6. Косолап, М.П. Система землеробства [Текст]: навч. посібник. / М.П. Косолап, О.П. Кротінов - Київ: «Логос», 2011. $352 \mathrm{c}$.

7. Мосіюк, І. П. Земельний ресурсний потенціал аграрного виробництва та раџіонального природокористування України [Текст] / I. П. Мосіюк, С. І. Мосіюк // Наук. Вісн. НУБіП Украӥни. Сер.: Економіка, аграрний менеджмент, бізнес. - 2011. - Вип. 163, ч.3. - C.259-261.

8. Томсон, П. Кому належсить земля у Великобританії? [Текст] / П. Томсон // Пропозииія. - 1997.- № 5.- C.8.

9. Шипулін, В. Д. Система земельного адміністрування: основи сучасної теорії [Текст]: навч. посібник / В. Д. Шипулін; Харків. нац. ун-т міськ. госп-ва ім. О. М. Бекетова - Харків: ХНУМГ ім. О. М. Бекетова, 2016. - 225 с.

10. Юрченко, А. Стан земельної політики в Україні [Текст] / А. Юрченко // Державна земельна політика в Україні: матер. круглого столу "Стан і стратегія сучас- 
ної земельної політики в Україні". - 21 травня 2009 р. К.: Вид во "Либідь", 2009. - С. 75-85.

11. Jantien E. Stoter. (2003) 3D aspects of property transactions: comparison of registration of 3D properties in the Netherlands and Denmark.

12. Mamonov, K., Nesterenko, S., Radzinskaya, Y., Palama,r A. (2019) The method for assessing the urban land investment attractiveness. Geodesy and Cartography, 321-327.

Рецензент: доктор технічних наук, професор, професор кафедри земельного адміністрування та геоінформаційних систем К.О. Метешкін, Харківський національний університет міського господарства імені О.М. Бекетова, Харків, Україна

Автор: МАМОНОВ Костянтин Анатолійович д.е.н., професор, професор кафедри земельного адміністрування та геоінформаційних систем Харківський національний університет міського господарства імені О. М. Бекетова E-mail-kostia.mamonov2017@gmail.com ID ORCID: http://orcid.org/0000-0002-0797-2609
Автор: ФРОЛОВ В'ячеслав Олександрович аспірант кафедри земельного адміністрування та геоінформачійних систем

Харківський національний університет міського господарства імені О. М. Бекетова

E-mail-frolgis@gmail.com

Автор: КОНДРАТЮК Іван Володимирович директор, інженер-землевпорядник ТОВ «Геодезично-вишукувальний иентр»

E-mail-nesterenkosg34@gmail.com

Автор: КАНІВЕЦЬ Олена Миколаївна старший викладач кафедри геодезї та землеустрою

Сумський національний аграрний університет

E-mail-leva1205@ukr.net

\title{
ТЕРИТОРІАЛЬНИЙ РОЗВИТОК ВИКОРИСТАННЯ ЗЕМЕЛЬ РЕГІОНІВ: КОНЦЕПТУАЛЬНІ ПОЛОЖЕННЯ, ПРОБЛЕМИ ТА МЕТОДОЛОГІЧНИЙ ПІДХІД ДО ОЦІНКИ
}

\author{
К.А. Мамонов, ${ }^{1}$ В.О. Фролов, ${ }^{1}$ I.В. Кондратюк, ${ }^{2}$ О.М. Канівець ${ }^{3}$
}

\author{
${ }^{1}$ Харківський національний університет міського господарства імені О.М. Бекетова, Україна \\ ${ }^{2}$ ТОВ «Геодезично-вишукувальний центр», Україна \\ ${ }^{3}$ Сумський національний аграрний університет, Україна
}

Визначено актуальність та своєчасність забезпечення територіального розвитку землекористування на регіональному рівні. Метою дослідження є розробка концептуальних положень та методологічного підходу до визначення та оцінки територіального розвитку землекористування в регіонах. Для досягнення цієї мети вирішуються такі завдання: виявлення проблем у системі забезпечення територіального розвитку землекористування в регіонах; формування конщептуальних положень щяодо визначення територіального розвитку регіональних земель; розробка методологічного підходу до оцінки рівня територіального розвитку використання земель регіонів. Виявлено проблемні аспекти та запропоновано визначення поняття «територіальний розвиток землекористування в регіоні», яке включає багатовимірність та особливості територіального розвитку, напрями змін просторових, містобудівних, інвестиційних та екологічних факторів, дозволяють створити теоретико-методологічну платформу, засновану на застосуванні концептуальної схеми системного підходу та виділити домінуючий напрямок вирішення проблеми підвищення ефективності використання земельних ділянок для територіального розвитку регіонів, визначити проблемні аспекти, щчо виникають у сфері земельних відносин, поєднати позитивні напрямки існуючих підходів та розробити комплексні інструменти для впровадження сучасних методів та моделей.

Визначено напрями розробки та реалізачії методологічного підходу до оцінки територіального розвитку використання земель в регіонах. У результаті дослідження визначено інтегральний показник територіального розвитку використання земель в регіонах, значення якого вказує на необхідність зміни його тенденцій шляхом застосування заходів та розробки науково обгрунтованих рекомендацій щуодо забезпечення територіального розвитку використання земель для переходу від помірного сиенарію до сценарію зростання.

Визначений інтегральний показник територіального розвитку використання земель регіонів дозволяє створити кількісне підгрунтя для прийняття рімень та зростання ефективності землекористування у системі регіонального розвитку.

Ключові слова: використання земель, територіальний розвиток регіонів, концептуальні положення, методичний підхід, оцінка. 